\title{
Description of a new species of Subepona Dolin et Lozouet, 2004 (Mollusca: Cypraeoidea) from the Lutetian (Middle Eocene) of Hungary
}

\author{
Jean-Michel PACAUD ${ }^{1} \&$ Zoltán VICIÁN ${ }^{2}$ \\ ${ }^{1}$ CR2P Centre de Recherche en Paléontologie - Paris Muséum national d'Histoire naturelle, \\ Sorbonne Université, CNRS, 8 rue Buffon, CP 38, 75005 Paris, France.E-mail : pacaud@mnhn.fr; \\ ${ }^{2}$ H-1185 Budapest, Neptun utca 86.10/42, Hungary.E-mail: kauri72@gmail.com
}

\begin{abstract}
The fossil gastropods from the Lutetian (Middle Eocene) of Hungary which have been attributed so far to Eopustularia balinka Fehse, 2010 are not consistent with this Bartonian (Middle Eocene) species for which this name has been introduced by Fehse, but they represent a different species. Until now they were considered as Eopustularia; however, these two species are here discussed in the genus Subepona. The new species Subepona hungarica n. sp. is introduced. With 15 figures.
\end{abstract}

Key words - Bartonian, Cypraeidae, Cypraeoidea, Eocene, Gastropoda, Hungary, Lutetian, new species, taxonomy

\section{INTRODUCTION}

As it was recently discussed by PACAud (2018a), the genus Eopustularia Fehse, 2010 (type species: Eopustularia balinka Fehse, 2010 by original designation) is an obvious subjective synonym of Subepona (type species: Subepona herrerensis Dolin et Lozouet, 2004 by original designation). All of the shell characters, in particular the rostrated adapical edge, the important lateral margination and the development of the exhalant canal and the siphonal canal, refer to the genus Subepona. The species designated by Dolin \& Lozouet (2004) and Dolin \& PACAUd (2009) as Subepona do not possess the characters of the genus Proadusta (type species: Cypraea denticulina Sacco, 1894 by subsequent designation: PACAUd 2018a; ICZN 1999 Art 70.3). Moreover, they were considered as Proadusta by FeHSE (2009), who more recently considered them as Eopustularia (FEHSE 2010: p. 5). Furthermore, the holotype (ZMB Ga.5797.1) of Eopustularia balinka Fehse, 2010 from the Bartonian (Middle Eocene) of Roncà (Province of Verona, Italy) differs from some of the paratypes, especially those from the Lutetian (Middle Eocene) of Balinka (Hungary). The holotype is not different from Subepona antiqua (Lamarck, 1811) described from the Bartonian of Roncà (Italy) (Figs 1-3), for which we have designated a neotype (DoLIN \& PACAUD 
2009: p. 304, pl. 4, figs 12-13; MNHN.F.J04452). In this context, and bearing in mind the previous points, we consider E. balink a Fehse, 2010 as a junior subjective synonym of the species Subepona antiqua described by LAMARCK (1811). The situation is similar for the taxon Conocypraea gregorioi Schilder, 1929 (holotype: SMF 1303, Schilder Collection), explicitly introduced for the specimen figured by DE GREGorio (1896: p. 37, pl. 3, fig. 10) as Cypraea (Epona) moloni Bayan, 1870, which also comes from Roncà and whose figure unambiguously corresponds to Subepona antiqua (Lamarck, 1811) and not to the species from the lower Lutetian of Italy (DolIN \& PACAUD 2009: p. 284, pl. 4, figs 7-11). In addition, the specimen of Roncà, figured as Eopustularia gregorioi (Schilder, 1929) by FEHSE (2010: pl. 5, fig. 6), does not show any difference from Subepona antiqua (Lamarck, 1811).

As a consequence, the species from the Lutetian of Balinka (Hungary) was already reported from the Lutetian of Gánt (SzÖTs 1953: p. 181, pl. 6, Figs 1-2; 1956: p. 44), Dudar (STRAUSz 1966: p. 128), and Iszkaszentgyörgy (KECS KEMÉTIKÖRMENDY \& MÉszÁROS 1980: p. 59, 103, pl. 10, fig. 8) respectively under the erroneous names of Pustularia moloni (Bayan, 1870) and Cypraea (Proadusta) moloni (Bayan, 1870). Recently Lorenz (2014: p. 11, fig. 3) and Vicián et al. (2017: p. 267, pl. 1, figs 5-7) based on a well-preserved, not deformed specimen from Gánt (Szőlö-hegy), recognized that Hungarian specimens represent a new species which should be described. This was already the approach we adopted: «Subepona antiqua s'apparente davantage à Pustularia moloni sensu Szöts (1953,

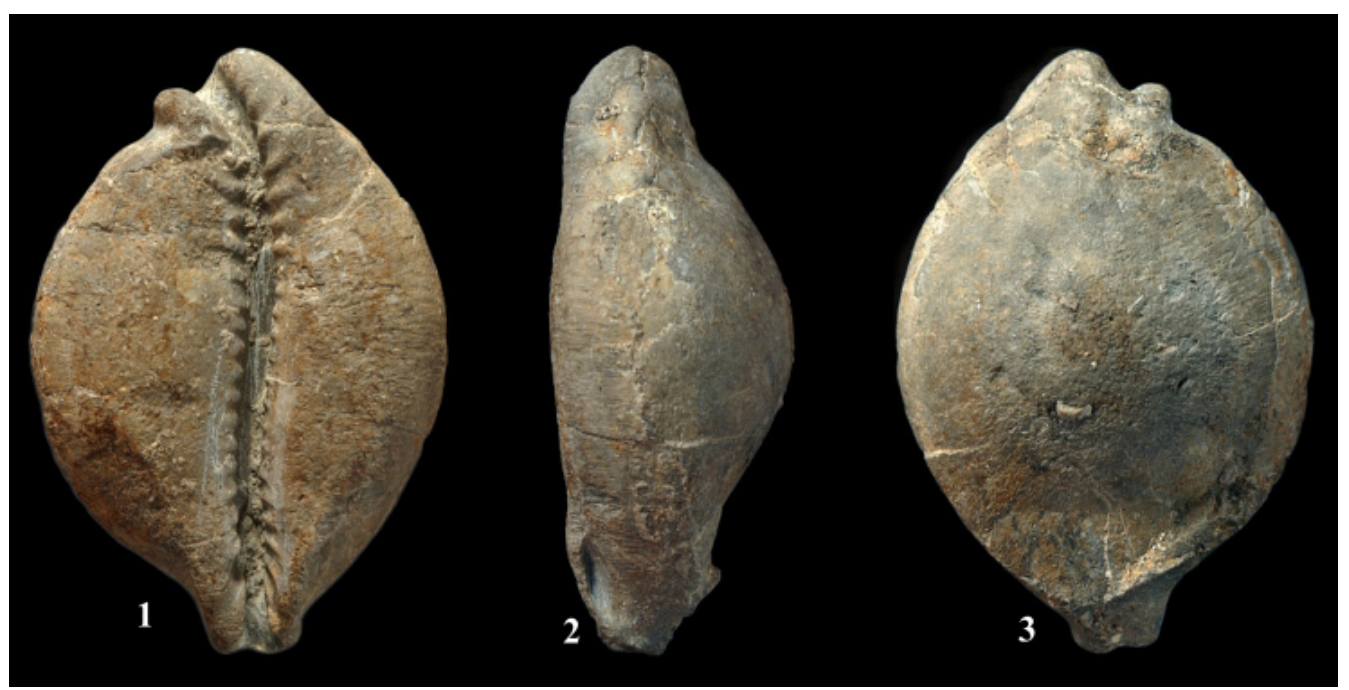

Figs 1-3. Subepona antiqua (Lamarck, 1811), Bartonian, Roncà (Italy), neotype, MNHN.F.J04452 (Hebert \& Munier-Chalmas Coll.), H: 28.2 mm, Photo by Christian Lemzaouda - MNHN. - Fig. 1. Ventral view. - Fig. 2. Side view. - Fig. 3. Dorsal view 
p. 181, pl. 6, fig. 1-2) de l'Éocène moyen de Hongrie. Cette petite morpho-espèce (hauteur: $18.5 \mathrm{~mm}$ ), beaucoup plus ampoulée, qui présente une denticulation de la lèvre externe encore plus rare, se prolongeant en outre sur près d'un tiers de la sole ventrale de la lèvre externe, reste à nommer» (Dolin \& PACAUD 2009: p. 304) and «Il s'en suit que l'espèce du Lutétien de Balinka (Hongrie) [...] correspond à une espèce inédite et doit être renommée» (PACAUD 2018a: p. 24).

\section{SYSTEMATIC PALAEONTOLOGY}

The terminology of the main morphological characters of the shells proposed by Dolin \& Lozouet (2004) and PACAud (2018a) is used in this study.

Abbreviations used in the text: MNHN.F = Muséum national d'Histoire naturelle, Collection de Paléontologie (Paris, France); HNHM = Hungarian Natural History Museum (Budapest, Hungary); UCBL = Université Claude Bernard (Lyon, France); ZMB = Natural History Museum of the Humboldt University (Berlin, Germany); ZVH = Collection Zoltán Vicián (Budapest, Hungary).

Superfamily Cypraeoidea Rafinesque, 1815

Family Cypraeidae Rafinesque, 1815

Genus Subepona Dolin et Lozouet, 2004

Type species - Subepona herrerensis Dolin et Lozouet, 2004 by orig. designation.

[Subepona herrensis Dolin et Lozouet, 2004 is an incorrect original spelling]

Synonymy: Eopustularia Fehse, 2010 (type species - Eopustularia balinka Fehse, 2010 by original designation).

Subepona hungarica n. sp.

(Figs 4-15)

1953 Pustularia moloni (Bayan, 1870) - SzöTs, p. 181, pl. 6, figs 1-2.

1956 Pustularia moloni (Bayan) - Szöts, p. 44.

1966 Cypraea (Proadusta) moloni (Bayan) - STRAUSz, p. 128.

2009 Proadusta cf. compacta Schilder, 1925 - FeHSE, p. 10, pl. 1, fig. 5.

2009 Proadusta gregorioi (Schilder, 1929) - FEHSE, p. 12, pl. 1, fig. 6.

2009 Proadusta sp. aff. speyeri (Mayer-Eymar, 1894) - FEHSE, p. 14, pl. 2, fig. 1.

2009 Subepona sp. - Dolin \& PACAUd, p. 304.

partim 2010 Eopustularia balinka - FEHSE, p. 6, pl. 5, figs 4-5 (non 1-3).

2014 Eopustularia balinka Fehse, 2010 - LORENZ, p. 11, fig. 3.

2016 Proadusta gregorioi (Schilder, 1929) - HESSEL, p. 157.

2017 Eopustularia balinka Fehse, 2010 - Vicián et al., p. 267, pl. 1, figs 5-7.

2018 a Subepona sp. - PACAUd, p. 24.

2018 bubepona "balinka" Fehse, 2010 - PACAUD, p. 10, Table 1.

Holotype - MNHN.F.A70304 (Vicián Coll., no. 5687). 
Paratypes - MNHN.F.A70305 and A70306 (Vicián Coll., no. 1870 and 5688), HNHM PAL 2018.21.1. (Vicián Coll., no. 5665), Vicián Coll. (no. 1849, 5674, 5669 and 5685).

Type locality - Gánt, Gránás, Fejér County (Hungary).

Type horizon - Lutetian (Middle Eocene).

Dimensions - Table 1.

Etymology - From his original country.

Other materials examined - Gánt, Gránás (Hungary), Lutetian, Middle Eocene: Vicián Coll.: 4 specimens: no. 1847, 2027, 2030, 2032; Stichting Schepsel Schelp: Hessel Coll.: 1 specimen, no. 62803; Mecsértelep, Fejér County (Hungary): Vicián Coll.: 3 specimens: no. 942, 1552 and 7210; Debayeux Coll.: 6 specimens.

Diagnosis - Small Subepona species, with rostrated extremities, coarse labial and weaker columellar teeth. Margins are calloused, sharply edged. Preserved colour pattern under UV light: ventrum and sides whitish, dorsum darker with bright circular dots.

Description - The shell is small, thick, stocky, hemispherical, and high profile, with a smooth surface, strongly marginalized edges and prominent extremities. The maximal dorso-ventral diameter is located in the posterior part of the shell. The ventral sole is slightly convex. The spire is protruding, forming a slight depression limited by the suture of the uncovered last round behind the adapical bridge. The siphonal canal is long, deep and forms a prominent annular bridge, strongly marked, aciculate at its extremities, and clearly distinct from the curve of the shell. The terminal fold, in the form of a thin and sharp blade, is long, straight and extended by a short, inclined internal blade, which is of the same thickness.

Table 1. Dimensions of Subepona hungarica n. sp. specimens (in $\mathrm{mm}$ )

\begin{tabular}{lcccc}
\hline Specimen & no. & Height & Width & $\begin{array}{c}\text { Dorso-ventral } \\
\text { diameter }\end{array}$ \\
\hline Paratype 1 & MNHN.F.A70305 & 17.4 & 11.6 & 8.8 \\
Specimen & ZVH 7210 & 17.5 & 10.9 & 9.0 \\
Holotype & MNHN.F.A70304 & 18.0 & 12.0 & 9.3 \\
Paratype 2 & ZVH 5674 & 18.3 & 11.5 & 9.2 \\
Paratype 3 & PAL 2018.21.1. & 18.7 & 11.9 & 9.2 \\
Paratype 4 & MNHN.F.A70306 & 18.8 & 12.9 & 9.9 \\
Paratype 5 & ZVH 5685 & 19.9 & 13.2 & 9.9 \\
Specimen & ZVH 1552 & 20.2 & 12.3 & 9.4 \\
Paratype 6 & ZVH 5669 & 20.3 & 14.0 & 11.1 \\
Specimen & ZVH 942 & 21.2 & 13.0 & 10.8 \\
Paratype 7 & ZVH 1849 & 21.8 & 13.7 & 11.0 \\
\hline
\end{tabular}




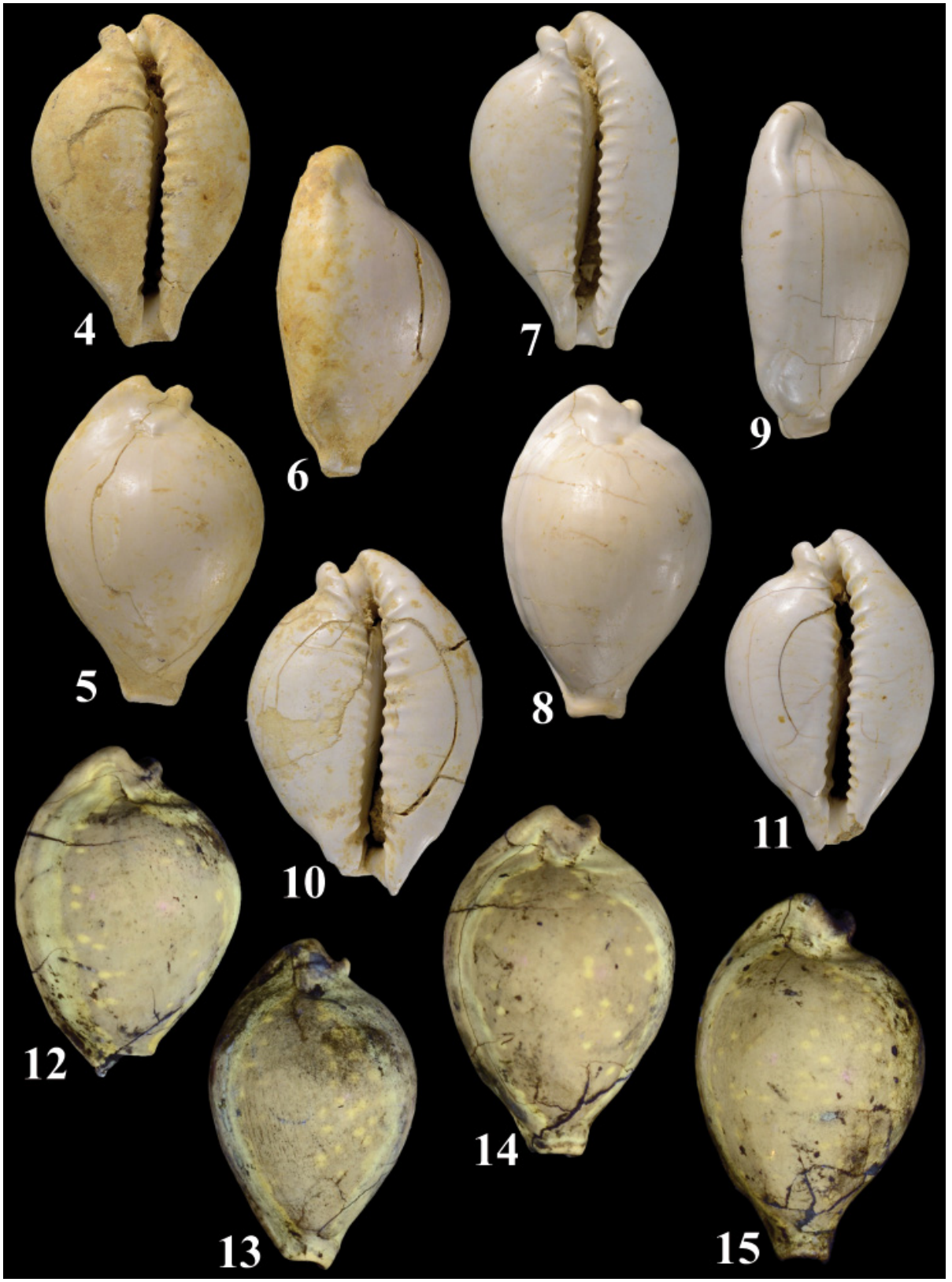

Figs 4-15. Subepona hungarica n. sp., Lutetian, Gánt, Gránás (Hungary). - Figs 4-6. Holotype, MNHN.F.A70304, H: 18.0 mm. - Fig. 4. Ventral view. - Fig. 5. Dorsal view. - Fig. 6. Side view. Figs 7-9. Paratype, Vicián Coll., no. 5674, H: 18.3 mm. - Fig. 7. Ventral view. - Fig. 8. Dorsal view. - Fig. 9. Side view. - Fig. 10. Paratype, MNHN.F.A70306, ventral view, H: $18.8 \mathrm{~mm}$. - Fig. 11. Paratype, MNHN.F.A70305, ventral view, H: $17.4 \mathrm{~mm}$. - Figs 12-15. Specimens under UV light with the residual colour pattern. - Fig. 12. Paratype, MNHN.F.A70306, dorsal view, H: $18.8 \mathrm{~mm}$. - Fig. 13. Paratype, HNHM PAL 2018.21.1., dorsal view, H: 18.7 mm. - Fig. 14. Paratype, Vicián Coll., no. 5685, dorsal view, H: 19.9 mm. - Fig. 15. Paratype, Vicián Coll., no. 1849, dorsal view, H: 21.8 mm 
The aperture is relatively narrow, rectilinear, deviated in its adapical third and with parallel edges. The fossula is small, smooth and has a slightly thickened margin. The columellar area is broad and flattened. The inner lip bears 14 powerful and strong denticles, including the first abapical denticles, which are mostly limited by abrupt angulation, and whose last parietal denticles are developed into long funicles, sometimes to the end of the adapical ridge of the inner edge of the aperture. Its external lip is callous, strongly marginalized, depressed in its former quarter and raised laterally, flattened. It contains 17 powerful denticles, widely spaced, extended on nearly $1 / 3$ of its ventral surface, its exhalant channel is short, broad, weakly deviated adapically and forming a thick, protruding bridge, which is clearly circumscribed by the adapical edge of the internal edge of the aperture. Exposure under UV light shows traces of residual colour pattern (Figs 12-15), which consists of many fluorescent spots on a dark background. They are small, circular in shape, uniform in size, mostly distributed on the flanks and absent from the highest part of the dorsal surface. The intensity of the spots, their size and distribution vary from one individual to another. The dorsal surface has a large dark area. The rest of the shell, ventral side, bridges and flanks, shows a fluorescent light zone.

Remarks - This small-sized species (holotype: $18.0 \mathrm{~mm}$ ), which much more bulb-shaped than any of its congeners, is characterized by a rare outer lip denticulation, extending over nearly a third of the ventral sole of the external lip and by parietal denticles which develop into long funicules on the inner lip, sometimes reaching the end of the adapical edge of the inner portion of the opening. These characters are sufficient to discriminate it. Subepona moloni (Bayan, 1870) from the Italian lower Lutetian (BAYAN 1870a: p. 460, 481; 1870b: p. 59, no. 83, pl. 9, figs 1-1a; De Gregorio 1880: pp. 37-38, pl. 1, fig. 31; Dolin \& PACAUD 2009: p. 284, pl. 4, figs 7-11), with which it was confused by Szöts (1953; 1956) and STRAUSZ (1966), differs from Lutetian species of Hungary by its much larger dimensions (the lectotype UCBL-EM 31325, Bayan Coll., copy MNHN.F.A24225 has a height of $30.7 \mathrm{~mm}$ ), its regularly oval-subglobular shape, by the position of maximal elevation in the central part of the dorsal surface of the shell and by its extremely fine and numerous denticulation ( 23 denticles on the inner lip, 28 denticles on the outer lip). As discussed above, the holotype [ZMB Ga.5797.1] and the two paratypes [ZMB Ga.5797.2 and Ga.5797.3] of Eopustularia balinka Fehse, 2010 from the Bartonian (Middle Eocene) of Roncà (Italy) show no differences from Subepona antiqua (Lamarck, 1811) described from the same deposits (FEHSE 2010: pl. 5, figs.1-3). The Italian species (Figs 1-3) differs from $S$. hungarica n. sp. by its significantly larger dimensions (the neotype MNHN.F.J04452 has a height of $28.2 \mathrm{~mm}$, the lost syntype from the Faujas de Saint Fond Collection had a height of $29.0 \mathrm{~mm}$ ), by its pyriform, stockier and more clearly hemispherical curve, by the thicker, more prolonged, more 
protruding, more clearly deformed and dorsally rolled back adapical end of the inner lip, by its tighter and more numerous denticulation (17 denticles on the inner lip, 22 denticles on the outer lip). The exhalant channel is narrower and more elongate. The adapical end of the outer lip is longer.

Acknowledgements - We thank Philippe Loubry (MNHN/CNRS) for the photographs and for the computer graphics of the figures, Rudi Hessel (Museum of Conchyliology Stichting Schepsel Schelp of Utrecht, Netherlands), Daniel Ledon and Didier Debayeux for the material that they kindly made available to us for this study, Marie-Béatrice Forel (MNHN) and Julien Devillez (MNHN) for their help in writing the English manuscript.

\section{REFERENCES}

BAYAN F. 1870a: Sur les terrains tertiaires de la Vénétie. - Bulletin de la Société Géologique de France (2) 27: 444-486.

BAYAN F. 1870b: Études faites dans la collection de l'École des Mines sur des fossiles nouveaux ou mal connus. $1^{\text {er }}$ fascicule, Mollusques tertiaires, Savy, Paris, 81 pp., 10 pls.

De Gregorio A. 1880: Fauna di San Giovanni Ilarione(Parisiano). Parte 1a : Cefalopodi e Gastropodi, Montaina \& C., Palermo, 110 pp., 9 pls.

De Gregorio A. 1896: Description des faunes tertiaires de la Vénétie. Monographie de la faune éocènique de Roncà, avec une [sic] appendice sur les fossiles de Monte Pulli. - Annales de Géologie et de Paléontologie 21: 1-163, pls 1-27.

Dolin L. \& Lozouet P. 2004: Nouvelles espèces de Gastéropodes (Mollusca: Gastropoda) de l'Oligocène et du Miocène inférieur de l'Aquitaine (Sud-Ouest de la France). Partie 3. Cypraeidae et Ovulidae. - Cossmanniana hors-série 4: 1-164, pls 1-36.

Dolin L. \& Pacaud J.-M. 2009: Les Cypraeoidea et Velutinoidea (Mollusca, Caenogastropoda) du Lutétien inférieur du Vicentin et du Véronais (nord-est de l'Italie). - Revue de Paléobiologie 28(2): 277-314, pls 1-8.

Fehse D. 2009: Katalog der fossilen Cypraeoidea (Mollusca: Gastropoda) in der sammlung Franz Alfred Schilder. - 4. Die Unterfamilie Erosariinae Schilder, 1924. - Acta Conchyliorum 10: 2-56, pls 1-6.

FeHSE D. 2010: New Species of fossil Cypraeoidea from Europe and Australia (Mollusca: Gastropoda). - Palaeontographica Abteilung 292(1-3): 1-19, pls 1-5. https://doi.org/10.1127/pala/292/2010/1

Hessel P. 2016: Stichting Schepsel Schelpfrom. 1991-2016. Part. 1 (Foundation Creature Shell), Stichting Schepsel Schelp, Rhenen, 296 pp.

I.C.Z.N. 1999: International Code of Zoological Nomenclature (Fourth edition). The Natural History Museum, London, 306 pp. https://doi.org/10.5962/bhl.title.50608

KeCsKemÉti-Körmendy A. \& MÉszÁros N. 1980: Az eocén szigettengeri fácies puhatestü faunája a Bakony keleti peremén. (Mollusques éocènes du secteur oriental de la Montagne du Bakony (Faciès archipélagique.) - Annales Instituti Geologici Publici Hungarici 63(2): 7-116, pls 1-13.

LAmarck J.-B. 1811: Suite du genre Porcelaine. - Annales du Muséum d'Histoire Naturelle 16(92): 89-114.

Lorenz F. 2014: Monograph of the genus Pustularia (Gastropoda: Cypraeidae). - ConchBooks, Harxheim, 130 pp. 
PACAud J.-M. 2018a: Les Cypraeoidea (Mollusca, Caenogastropoda) du Priabonien (Éocène supérieur) de Dnipro (Oblast de Dnipropetrovsk, Ukraine). Partie 1: Cypraeidae. - Xenophora Taxonomy 20: 14-33, pls 1-4.

PaCAud J.-M. 2018b: Présence à l'Éocène moyen du bassin de Paris de Subepona brackleshamensis (Schilder, 1829) (Mollusca: Cypraeoidea), espèce décrite de l'Éocène d'Angleterre. - Folia Conchyliologica 46: 5-12, pl. 1.

STrausz L. 1966: Dudari eocén csigák. (Les Gastropodes de l'Éocène de Dudar.) - Geologica Hungarica, series Palaeontologica 33: 1-200, pls 1-24.

SzÖTs E. K. 1953: Magyarország eocén puhatestüi. 1. Gántkörnyéki eocén puhatestűek. (Mollusques éocènes de la Hongrie. 1. Les Mollusques éocènes des environs de Gánt). - Geologica Hungarica, series Palaeontologica 22: 5-245 (115-238), pls 1-10.

Szöts E. K. 1956: Magyarország eocén (paleogén) képződményei. (L'Éocène (Paléogène) de la Hongrie). - Geologica Hungarica, series Palaeontologica 9: 1-320, pls 1-22.

VICIÁN Z., KROCK H. \& KovÁcs Z. 2017: New gastropod records from the Cenozoic of Hungary. Földtani Közlöny 147(3): 265-282, pls 1-3. https://doi.org/10.23928/foldt.kozl.2017.147.3.265 